OPEN ACCESS

Edited by:

Vincent Poitout,

Université de Montréal, Canada

Reviewed by:

Feyza Engin,

University of Wisconsin-Madison,

United States

Neha Shrestha,

University of Michigan, United States

${ }^{*}$ Correspondence:

Ana Maria Vacaru

ana.vacaru@icbp.ro

Specialty section:

This article was submitted to

Diabetes: Molecular Mechanisms, a section of the journal

Frontiers in Endocrinology

Received: 05 October 2020 Accepted: 24 November 2020

Published: 19 January 2021

Citation:

Lenghel A, Gheorghita AM, Vacaru AM and Vacaru A-M (2021) What Is the

Sweetest Unfolded Protein

Response Flavor for the $\beta$-cell?

That is the Question.

Front. Endocrinol. 11:614123.

doi: 10.3389/fendo.2020.614123

\section{What Is the Sweetest UPR Flavor for the $\beta$-cell? That Is the Question}

\author{
Alina Lenghel, Alina Maria Gheorghita, Andrei Mircea Vacaru and Ana-Maria Vacaru* \\ Institute for Cellular Biology and Pathology "Nicolae Simionescu", Bucharest, Romania
}

Unfolded protein response (UPR) is a process conserved from yeasts to mammals and, based on the generally accepted dogma, helps the secretory performance of a cell, by improving its capacity to cope with a burden in the endoplasmic reticulum (ER). The ER of $\beta$-cells, "professional secretory cells", has to manage tremendous amounts of insulin, which elicits a strong pressure on the ER intrinsic folding capacity. Thus, the constant demand for insulin production results in misfolded proinsulin, triggering a physiological upregulation of UPR to restore homeostasis. Most diabetic disorders are characterized by the loss of functional $\beta$-cells, and the pathological side of UPR plays an instrumental role. The transition from a homeostatic to a pathological UPR that ultimately leads to insulinproducing $\beta$-cell decay entails complex cellular processes and molecular mechanisms which remain poorly described so far. Here, we summarize important processes that are coupled with or driven by UPR in $\beta$-cells, such as proliferation, inflammation and dedifferentiation. We conclude that the UPR comes in different "flavors" and each of them is correlated with a specific outcome for the cell, for survival, differentiation, proliferation as well as cell death. All these greatly depend on the way UPR is triggered, however what exactly is the switch that favors the activation of one UPR as opposed to others is largely unknown. Substantial work needs to be done to progress the knowledge in this important emerging field as this will help in the development of novel and more efficient therapies for diabetes.

Keywords: unfolded protein response (UPR) pathway, $\beta$-cell proliferation, $\beta$-cell dedifferentiation, immune attack, heterogeneity

\section{INTRODUCTION}

Recently, increased stress of the endoplasmic reticulum (ER), or ER stress, has emerged as a critical regulator of transcription and translation events in diabetes (1-5). The ER supports correct protein folding that is essential to maintain protein homeostasis and cell survival; however, this process is remarkably sensitive as even minute modifications in the cellular milieu can result in protein misfolding $(6,7)$. Following nutrient stimulation, freshly transcribed insulin mRNA translated in the ER drives a 10-fold increase in insulin synthesis that represents about $50 \%$ of the total protein production by the $\beta$-cells $(7,8)$. This massive synthesis and its variations result in a constant hassle 
of the ER. To deal with this challenge, $\beta$-cells continuously supervise protein folding in the ER through a well conserved mechanism, the unfolded protein response (UPR) $(7,9)$.

Over the next sections, we will present how UPR is actively present during important stages of $\beta$-cell existence in physiological and pathological circumstances. We will focus on processes that are relevant for the development of potential therapies that target UPR. As such, we will address the role of UPR in proliferation, inflammation/inflammatory attack and dedifferentiation of $\beta$-cells.

\section{UPR AND DEVELOPMENT OF DIABETES}

UPR is a cellular process consisting of an intricate network of transducers and downstream target genes ensuring correct protein folding in the ER. UPR comprises of three major sensors: Protein kinase RNA-like endoplasmic reticulum kinase (PERK), endoribonuclease/kinase inositol-requiring enzyme 1 (IRE1, or ERN1), and activating transcription factor 6 (ATF6) $(10,11)$. These factors are localized in the ER membrane and they are able to sense and monitor through their luminal domains the status of protein folding in the ER (12-17). If an accumulation of unfolded proteins occurs, these transducers signal via their cytosolic domains either by direct targeted catalytic activities or by specific post-translational modulation. The precise mechanism that triggers UPR is still under debate (18-22), and most probably there is not a single mechanism involved, but rather the multiple concerted action of several ones, depending on cell type (23-25). The downstream effectors converge at the nucleus and induce UPR targets, finally restoring homeostasis via various processes described below.

PERK, upon oligomerization followed by autophosphorylation (26-28), phosphorylates the translation initiation factor 2 (eIF2 $\alpha$ ) inducing inhibition of mRNA translation through activation of a signaling cascade, thus reducing the ER protein load, and increasing ATF4 translation $(13,27,29,30)$. This results in overexpression of chaperones, antioxidant genes, but also of proapoptotic genes, such as CHOP, GADD34, ATF3 and TRB3 that contribute to $\beta$-cell apoptosis during terminal $\operatorname{UPR}(31,32)$. eIF $2 \alpha$ has a central role in stress management, being also targeted by other kinases in response to various kinds of stresses $(30,33-$ 36). This signaling cascade converging on eIF2 $\alpha$ phosphorylation followed by ATF4 activation is an adaptive pathway for cellular homeostasis restoration commonly known as Integrated Stress Response (ISR) $(37,38)$.

IRE1 possesses both kinase and endoribonuclease activities. When UPR is induced, dimerization and transautophosphorylation of IRE1 activates its RNase domain and results in splicing of $X b p 1$ pre-mRNA and overexpression of $\mathrm{XBP} 1 \mathrm{~s}$, a transcription factor that induces genes-encoding chaperones, ER-associated protein degradation (ERAD), and lipid biosynthetic enzymes (12, 17, 39-41). Additionally, IRE1 presents a nonspecific RNase activity responsible for degradation of mRNAs from ER vicinity, thus reducing import of proteins into the $\operatorname{ER}(26,42,43)$. During increased stress, the kinase activity of IRE1 is activated and initiates the apoptosis cascade mediated by signal-regulating kinase 1 (ASK1)/cJun amino terminal kinase (JNK) (44).

Upon UPR activation, ATF6 is translocated to the Golgi apparatus, where it is processed by Site- 1 and Site- 2 proteases (S1P/S2P) $(45,46)$. Once the cytosolic fragment (nuclear ATF6, or nATF6) is generated, it travels to the nucleus and induces transcription of UPR target genes (47-49). Alone or in combination with XBP1s, nATF6 acts on increasing synthesis of chaperones to aid with the misfolded proteins, of proteins involved in lipid synthesis to increase ER volume, and of genes responsible for the ERAD pathway. They work for restoring homeostasis by modulating the amount of ERmediated production of ER lipids and proteins necessary to accommodate variable requirements of ER protein folding and other functions in response to physiological and pathological conditions. If any of these mechanisms fail, the ER homeostasis is lost, a stressed UPR is induced and that ultimately results in cell apoptosis $(11,32,50-52)$.

In diabetes, overactivation of UPR leads to phosphorylation of IRE1, which results in degradation of proinsulin mRNA (5355 ) activation of JNK pathway, and splicing of XBP1 mRNA. $\mathrm{XBP} 1 \mathrm{~s}$ by itself or in cooperation with ATF6 induces expression of various ER chaperons, such as Herp1, EDEM, HRD1, p58IPK, and ERAD proteins, followed by swelling of the ER. Moreover, CHOP mRNA expression is induced by both ATF4 and XBP1s (5). By depleting $\mathrm{CHOP}$ in various diabetes models results in improved $\beta$-cell function and survival (56), although in NOD mice it is not the case (57). Surprisingly, TUDCA was able to increase the expression of Atf6 and XBP1 and increased $\beta$-cells survival, reduced islet inflammation and thus lower diabetes incidence in mouse models of diabetes (58). Therefore, in diabetes, the erroneous expression of ER chaperones may be responsible for the predisposition of the $\beta$-cell to a terminal UPR that culminates with cell death induced by $\mathrm{CHOP}$.

PERK-eiF2 $\alpha$-ATF4 and IRE1-XBP1s/ATF6 arms of the UPR are activated differently by glucose. Surprisingly, low glucose concentrations result in maximal activation of the first arm, while protein synthesis, ATP levels and the concentration of $\mathrm{Ca}^{2+}$ in the ER are low, whereas the second arm is inactive. The response to high glucose concentration is the rapid inhibition of the ISR, the splicing of Xbpl pre-mRNA and subsequent upregulation of XBP1s together with the downstream target genes to accommodate increased ER machinery load. Finely adjusting this adaptive response is indispensable to preserve the identity and function of $\beta$-cell (59).

\section{UPR IS VERY DYNAMIC AND DRIVES HETEROGENIC INSULIN EXPRESSION}

Xin and collaborators have shown that in healthy human subjects, $\beta$-cells go through different active states to accommodate insulin requirements that are characterized by different levels of UPR and insulin gene expression. They show that the transition between an active and prolonged insulin 
secretory state results in induction of a stressed UPR that diminishes the levels of secreted insulin. After a certain time, the UPR of the $\beta$-cell recovers at a basal level and the cells restart the production of insulin. They describe several cyclical individual states of $\beta$-cell stress in correlation with insulin secretion, and low apoptosis and dedifferentiation markers (60). UPR was induced in a subpopulation of $\beta$-cells that express low insulin levels (INS ${ }^{\text {low }} \mathrm{UPR}^{\mathrm{hi}}$ ) suggesting they represent a state of recovery from stress. Another population of $\beta$-cells was characterized by INS ${ }^{\text {hi }} \mathrm{UPR}^{\text {low }}$ and most likely represents a state of active production and secretion (60). Importantly, the insulin protein amounts are not always correlated with the mRNA levels. Apparently, in pancreases of type 1 diabetes (T1D) patients insulin protein levels were very low; nevertheless proinsulin and INS mRNA were still detected (61). It is not clear if this occurs due to dedifferentiation of $\beta$-cells or because more precursors of $\beta$-cells arise $(61,62)$. The characterization of different populations of $\beta$-cells based on their UPR and insulin levels is crucial in diabetes. It is important to know how these populations change during the disease progression, and where and when to intervene therapeutically to recover insulin homeostasis.

\section{$\beta$-CELLS WITH ACTIVE UPR PROLIFERATE}

One of the questions that puzzled scientists referred to how is $\beta$-cell mass regulation maintained? While it is already established that stem cells drive regeneration of tissues with fast turnover, such as skin, gut and blood, a stem cell pool has not yet been characterized for the pancreatic islets (63). Multiple studies demonstrated that $\beta$-cell mass adjusts in a dynamic way, in correlation with increased metabolic demand, or upon injury. Under most conditions, the major driver of postnatal islet cell expansion is the proliferation of already present $\beta$-cells (64).

Several studies suggested that UPR activation in vivo drives $\beta$-cell proliferation. Hodish and collaborators showed that overexpression of mutant proinsulin is correlated with both UPR activation and islet size increase (65). Inhibiting expression of PERK in adult mice resulted in increased proliferation of $\beta$-cells (66). In addition, another study established that ATF6 pathway that acts in response to the loss of PERK is regulating the pro-proliferative UPR mechanism rather than PERK. By using different murine models of diabetes (glucose-induced hyperglycemia mouse model; $\mathrm{db} / \mathrm{db}$ mice and Akita mice) as well as $\beta$-cells isolated from pancreatic donors, they argue that mild UPR drives ATF6induced proliferation of $\beta$-cells based on the insulin requirement. Moreover, they show that inhibition of ATF6 and IRE1 pathways reduce glucose-induced $\beta$-cell proliferation in vitro. However, chemical chaperones abrogated the proliferative effect on the $\beta$ cells (63). Human $\beta$-cells are less likely to respond well to stimulation, as they have a lower basal proliferation than mouse cells $(67,68)$. Importantly, there are studies showing proliferation of $\beta$-cells from donors upon UPR stimulation (63). A thorough study that characterized various $\beta$-cells subpopulation from healthy subjects showed that the majority of proliferating cells displayed low insulin expression correlated with activated UPR, with more proliferating cells in G1S cell cycle phase rather than in G2M (60).

\section{UPR AND INFLAMMATION IN $\beta$-CELLS}

The questions raised here are: does the dysregulated UPR from $\beta$-cells facilitate the immune attack, or vice-versa, the cytokines secreted by the immune cells induced upregulation of the UPR in $\beta$-cells, rendering them more susceptible to apoptosis? Many studies proved that both are true and mostly interdependent.

\section{Inflammatory Environment Triggers UPR Activation}

Recent work shows the importance of inflammation for UPR induction and $\beta$-cell fate in various diabetes contexts, especially in $\operatorname{T1D}(9,69)$. There, the progressive invasion of inflammatory cells, like T-cells, macrophages, dendritic cells, and natural killer cells within the islets leads to insulitis $(9,70-72)$. Due to insulitis, the access of numerous proinflammatory molecules and reactive oxygen species (ROS) to $\beta$-cells, like interleukin-1 $\beta$ (IL1 $\beta$ ), TNF, IFN- $\gamma$, IL17, and NO, is facilitated as these molecules are secreted by the invading immune cells. This results in apoptosis of $\beta$-cells $(73,74)$. Death of $\beta$-cells driven by cytokines entails induction of various transcription factors (NF- $\mathrm{KB}$ and STAT1), JNK, which in conjunction with a stressed UPR, end with activation of mitochondrial pathway of apoptosis $(73,75,76)$. Moreover, upon stimulation by pro-inflammatory cytokines, $\beta$-cells start expressing and secreting more cytokines and chemokines, resulting in a crosstalk between the immune cells and the $\beta$-cells $(77,78)$. As a consequence, many $\mathrm{T}$ cells get infiltrated into the islets and cause destruction of the $\beta$-cells initiating diabetes $(73,79,80)$.

The low grade inflammation present in the pancreas of T2D patients is responsible for recruitment of macrophages in the vicinity of the islets creating a pro-inflammatory milieu and inducing UPR $(81,82)$. A recent study provided direct evidence for the role of ER stress-induced inflammation in T2D. It revealed that by blocking IL23 and IL24, proinflammatory cytokines upregulated in the islets of T2D patients, the authors were able to partially decrease oxidative stress, UPR induction and restore glucose tolerance in obese mice. In addition, after reducing ROS with IL22, the improved UPR stress and $\beta$-cell function re-established glucose homeostasis (83).

\section{UPR Facilitates Inflammatory Attack of $\beta$-Cells}

This research topic got attention, as emerging data connects inflammatory responses to UPR in $\beta$-cells via the regulator of inflammation, $\mathrm{NF \kappa B}(84,85)$. Additionally, XBP1 seems to exert both pro- and anti-inflammatory effects in $\beta$-cells depending on the context established by the anti-apoptotic/anti-oxidative reaction as opposed to the pro-inflammatory response (47). Moreover, CHOP was shown to have a pro-inflammatory role in various disease models, upregulating pro-inflammatory 
cytokines (such as IL1 $\beta$, IL8) and chemokines (CCL2) in several tissues $(86,87)$. However, it is not clear how CHOP activates NF$\kappa \mathrm{B}$. In $\beta$-cells, studies show that the transcription factor NF- $\kappa \mathrm{B}$ is able to modulate the UPR upon activation by pro-inflammatory cytokines $(88,89)$. Reciprocally, the UPR was found to induce $\mathrm{NF}-\mathrm{\kappa B}$ activity in correlation with inflammatory responses, resulting in increased apoptosis and overexpression of cytokines and chemokines that may be responsible for $\beta$-cell death $(74,89,90)$.

\section{UPR IN DEDIFFERENTIATION OF $\beta$-CELLS}

It has been established that every cell from any organism, $\beta$-cells included, are derived by differentiation from embryonic stem cells (91). Differentiation toward $\beta$-cells involves synchronized and rigorously controlled induction/downregulation of certain transcription factors and effectors in a timely manner (59). Importantly, cellular differentiation is not unidirectional (92). Recent data has shown that specific factors can induce mature $\beta$ cells to lose their identity and phenotype and backslide to an underdifferentiated state, or in a progenitor-like condition. This phenomena is called dedifferentiation and has been involved in the pathology of diabetes (93-96), being a significant contributor of the reduction of functional $\beta$-cell mass $(62,97)$. Dedifferentiation of $\beta$-cells is characterized by reduced expression of $\beta$-cell-specific genes, that include essential transcription factors, insulin, genes responsible for glucose metabolism, genes required for protein processing and genes of the secretory pathway, accompanied by induction of genes that are usually repressed or lowly expressed in mature $\beta$-cell, such as the embryonic endocrine progenitor genes. Expression of these later genes is found in diabetic animals, in the islets $(59,62,94)$. The mechanisms involved in the dedifferentiation process are still under investigation and here, we will underline some possible implications of UPR.

In a recent study, Zhu and collaborators have demonstrated that overexpression of miR24 reduced ER stress-induced $\beta$-cells apoptosis and blocked INS mRNA degradation, though it induced dedifferentiation of $\beta$-cells (98). MiR24 was found to inactivate the IRE1 sensor. Importantly, they speculated that one of the downstream effectors of IRE1 was CHOP. As ATF4 was not affected by miR24, the assumption was that CHOP was not upregulated via the PERK/ATF4 pathway. Surprisingly, they demonstrated that XBP1s, effector downstream of IRE1, is responsible for the apoptosis of $\beta$-cells under terminal ER stress (98). In a T1D model, work from Engin's group has shown that downregulating IRE1 before insulitis appearance results in temporary dedifferentiation of $\beta$-cells proved to be beneficial as it made $\beta$-cells more resistant to the immune attack (99). These dedifferentiated $\beta$-cells expressed lower levels of autoantigens and of MHC class I molecules and upregulated their immune inhibitory markers $(99,100)$. It became apparent that interference with TGF $\beta$ signaling resulted in induction of several markers of $\beta$-cells maturation $(101,102)$ and reversed dedifferentiation (103). The E3 ligase Hsd1 and the cofactor
Sel1L represent well-conserved ERAD machinery (104) that has recently been linked to the preservation of $\beta$-cells identity via inhibition TGF $\beta$ pathway, while their survival and proliferation were not affected (105).

\section{CONCLUSIONS AND PERSPECTIVES}

The correlation between activation of UPR and their insulin gene expression was shown to divide $\beta$-cells into several populations that evolve from dynamic insulin secretion states to a stress recovery state when insulin production is decreased (60). This is an important aspect when developing new therapies that have a scope to mimic the heterogeneity of the $\beta$-cells. Strategies for regenerating $\beta$-cells should consider the importance to reintroduce these differences in the newlyemerged cells.

In the $\beta$-cells, there are functions of UPR that are ER stressindependent. Hassler and collaborators, by using mice with inducible $\beta$-cells-specific deletion of IRE1 $\alpha$, established the importance IRE1 $\alpha / \mathrm{XBP} 1 \mathrm{~s}$ pathway for glucose-stimulated insulin synthesis. The study revealed that this pathway regulates recruitment and structure of the ribosome, translation of pro-insulin mRNA, cleavage of the signal peptide, and inhibition of oxidative/inflammatory stress. Early activation of this UPR pathway appears to happen separately of ER stress and precedes the glucose-stimulated insulin synthesis (47).

Prolonged upregulation of a stressed UPR induces apoptosis, a process that involves JNK activation by the proinflammatory cytokines that act upon pancreatic $\beta$-cells through the progression of diabetes. It is not clear though the definitive mechanisms that pro-inflammatory cytokines use to induce IRE $1 \alpha$ and JNK in human $\beta$-cells. This will help build new strategies to inhibit the UPR-driven proapoptotic signals without disturbing the other homeostatic functions (70).

We previously defined the ER stress as a stressed/terminal/ decompensated UPR, the ultimate stage of UPR, with no recovery, when the cell enters the apoptosis pathway. One of the questions here is how do the cells get to the terminal UPR. What are the stages that precede it and can be targeted through therapies? We and others have challenged two different models for UPR activation: 1) the "rheostat model", when the UPR sensors and targets get activated in a concerted fashion and they are correlated with the level of stress - the more stress, the higher the UPR. This model is described by different subclasses that are characterized by the type and extent of the stress $(52,106) .2$ ) Some stressors induce a UPR subclass that causes a specific outcome, physiological or pathological. This could vary from "adaptive" to the "terminal" UPR, when the cell sees many facets of UPR through a combination of different arms that are activated differently. These are such broad definitions, and future thorough characterizations are necessary to address the precise role of each of them in the $\beta$-cells fate.

Possible therapies that use UPR for restoring $\beta$-cells homeostasis should consider the existing $\beta$-cell stress level and 
action inside a narrow safe range to overcome the excess and cell death. One possibility is employing agents that recover $\beta$-cell stress from terminal stage to the adaptive stage thus to facilitate the increase of $\beta$-cell mass through the mild stress. Therefore, there is a need for more tools for measuring and modulating $\beta$ cell stress in vivo.

\section{AUTHOR CONTRIBUTIONS}

AL, AG, AMV, and AnaMV read and reviewed the final version of the work, and participated in bibliographical research and design. AL assisted in the writing. AnaMV designed the concept and wrote the manuscript. All authors contributed to the article and approved the submitted version.

\section{REFERENCES}

1. Herbert TP, Laybutt DR. A Reevaluation of the Role of the Unfolded Protein Response in Islet Dysfunction: Maladaptation or a Failure to Adapt? Diabetes (2016) 65:1472-80. doi: 10.2337/db15-1633

2. Laybutt DR, Preston AM, Akerfeldt MC, Kench JG, Busch AK, Biankin AV, et al. Endoplasmic reticulum stress contributes to beta cell apoptosis in type 2 diabetes. Diabetologia (2007) 50:752-63. doi: 10.1007/s00125-006-0590-z

3. Marhfour I, Lopez XM, Lefkaditis D, Salmon I, Allagnat F, Richardson SJ, et al. Expression of endoplasmic reticulum stress markers in the islets of patients with type 1 diabetes. Diabetologia (2012) 55:2417-20. doi: 10.1007/s00125-012-2604-3

4. Plaisance V, Brajkovic S, Tenenbaum M, Favre D, Ezanno H, Bonnefond A, et al. Endoplasmic Reticulum Stress Links Oxidative Stress to Impaired Pancreatic Beta-Cell Function Caused by Human Oxidized LDL. PLoS One (2016) 11:e0163046. doi: 10.1371/journal. pone. 0163046

5. Rabhi N, Salas E, Froguel P, Annicotte JS. Role of the unfolded protein response in beta cell compensation and failure during diabetes. J Diabetes Res (2014) 2014:795171. doi: 10.1155/2014/795171

6. Araki K, Nagata K. Protein folding and quality control in the ER. Cold Spring Harb Perspect Biol (2011) 3:a007526. doi: 10.1101/cshperspect.a007526

7. Scheuner D, Kaufman RJ. The unfolded protein response: a pathway that links insulin demand with beta-cell failure and diabetes. Endocr Rev (2008) 29:317-33. doi: 10.1210/er.2007-0039

8. Liu M, Weiss MA, Arunagiri A, Yong J, Rege N, Sun J, et al. Biosynthesis, structure, and folding of the insulin precursor protein. Diabetes Obes Metab (2018) 20(Suppl 2):28-50. doi: 10.1111/dom.13378

9. Brozzi F, Eizirik DL. ER stress and the decline and fall of pancreatic beta cells in type 1 diabetes. Ups J Med Sci (2016) 121:133-9. doi: 10.3109/0300 9734.2015.1135217

10. Schroder M, Kaufman RJ. The mammalian unfolded protein response. Annu Rev Biochem (2005) 74:739-89. doi: 10.1146/annurev.biochem.73.011303.074134

11. Schroder M, Kaufman RJ. ER stress and the unfolded protein response. Mutat Res (2005) 569:29-63. doi: 10.1016/j.mrfmmm.2004.06.056

12. Cox JS, Walter P. A novel mechanism for regulating activity of a transcription factor that controls the unfolded protein response. Cell (1996) 87:391-404. doi: 10.1016/S0092-8674(00)81360-4

13. Harding HP, Novoa I, Zhang Y, Zeng H, Wek R, Schapira M, et al. Regulated translation initiation controls stress-induced gene expression in mammalian cells. Mol Cell (2000) 6:1099-108. doi: 10.1016/S1097-2765(00)00108-8

14. Harding HP, Zhang Y, Bertolotti A, Zeng H, Ron D. Perk is essential for translational regulation and cell survival during the unfolded protein response. Mol Cell (2000) 5:897-904. doi: 10.1016/S1097-2765(00) 80330-5

15. Sidrauski C, Walter P. The transmembrane kinase Irelp is a site-specific endonuclease that initiates mRNA splicing in the unfolded protein response. Cell (1997) 90:1031-9. doi: 10.1016/S0092-8674(00)80369-4

\section{FUNDING}

The research leading to these results has received funding from the NO Grants 2014-2021, under Project contract no. 21/2020 (RO-NO-2019-0544; BETAUPREG to AnaMV) and from a project co-financed by European Regional Development Fund through the Competitiveness Operational Program 2014-2020 (POC-A.1-A.1.1.4-E-2015, ID: P_37_668; DIABETER) and by Romanian Academy.

\section{ACKNOWLEDGMENTS}

The authors are grateful to Madalina Dumitrescu for productive discussions. We apologize to the many researchers whose work we could not cite due to space limitations.

16. Yoshida H, Haze K, Yanagi H, Yura T, Mori K. Identification of the cisacting endoplasmic reticulum stress response element responsible for transcriptional induction of mammalian glucose-regulated proteins. Involvement of basic leucine zipper transcription factors. J Biol Chem (1998) 273:33741-9. doi: 10.1074/jbc.273.50.33741

17. Yoshida H, Matsui T, Yamamoto A, Okada T, Mori K. XBP1 mRNA is induced by ATF6 and spliced by IRE1 in response to ER stress to produce a highly active transcription factor. Cell (2001) 107:881-91. doi: 10.1016/ S0092-8674(01)00611-0

18. Acosta-Alvear D, Karagoz GE, Frohlich F, Li H, Walther TC, Walter P. The unfolded protein response and endoplasmic reticulum protein targeting machineries converge on the stress sensor IRE1. Elife (2018) 7:e43036. doi: 10.7554/eLife.43036

19. Carrara M, Prischi F, Nowak PR, Ali MM. Crystal structures reveal transient PERK luminal domain tetramerization in endoplasmic reticulum stress signaling. EMBO J (2015) 34:1589-600. doi: 10.15252/embj.201489183

20. Karagoz GE, Acosta-Alvear D, Nguyen HT, Lee CP, Chu F, Walter P. An unfolded protein-induced conformational switch activates mammalian IRE1. Elife (2017) 6:e30700. doi: 10.7554/eLife.30700

21. Kopp MC, Larburu N, Durairaj V, Adams CJ, Ali MMU. UPR proteins IRE1 and PERK switch BiP from chaperone to ER stress sensor. Nat Struct Mol Biol (2019) 26:1053-62. doi: 10.1038/s41594-019-0324-9

22. Kopp MC, Nowak PR, Larburu N, Adams CJ, Ali MM. In vitro FRET analysis of IRE1 and BiP association and dissociation upon endoplasmic reticulum stress. Elife (2018) 7:e30257. doi: 10.7554/eLife.30257

23. Adams CJ, Kopp MC, Larburu N, Nowak PR, Ali MMU. Structure and Molecular Mechanism of ER Stress Signaling by the Unfolded Protein Response Signal Activator IRE1. Front Mol Biosci (2019) 6:11. doi: 10.3389/fmolb.2019.00011

24. Karagoz GE, Acosta-Alvear D, Walter P. The Unfolded Protein Response: Detecting and Responding to Fluctuations in the Protein-Folding Capacity of the Endoplasmic Reticulum. Cold Spring Harb Perspect Biol (2019) 11: a033886. doi: 10.1101/cshperspect.a033886

25. Pobre KFR, Poet GJ, Hendershot LM. The endoplasmic reticulum (ER) chaperone $\mathrm{BiP}$ is a master regulator of ER functions: Getting by with a little help from ERdj friends. J Biol Chem (2019) 294:2098-108. doi: 10.1074/ jbc.REV118.002804

26. Bertolotti A, Zhang Y, Hendershot LM, Harding HP, Ron D. Dynamic interaction of $\mathrm{BiP}$ and $\mathrm{ER}$ stress transducers in the unfolded-protein response. Nat Cell Biol (2000) 2:326-32. doi: 10.1038/35014014

27. Harding HP, Zhang Y, Ron D. Protein translation and folding are coupled by an endoplasmic-reticulum-resident kinase. Nature (1999) 397:271-4. doi: $10.1038 / 16729$

28. Marciniak SJ, Garcia-Bonilla L, Hu J, Harding HP, Ron D. Activationdependent substrate recruitment by the eukaryotic translation initiation factor 2 kinase PERK. J Cell Biol (2006) 172:201-9. doi: 10.1083/ jcb.200508099 
29. Harding HP, Zhang Y, Zeng H, Novoa I, Lu PD, Calfon M, et al. An integrated stress response regulates amino acid metabolism and resistance to oxidative stress. Mol Cell (2003) 11:619-33. doi: 10.1016/S1097-2765(03) 00105-9

30. Suragani RN, Zachariah RS, Velazquez JG, Liu S, Sun CW, Townes TM, et al. Heme-regulated eIF2alpha kinase activated Atf4 signaling pathway in oxidative stress and erythropoiesis. Blood (2012) 119:5276-84. doi: 10.1182/blood-2011-10-388132

31. Lin JH, Li H, Yasumura D, Cohen HR, Zhang C, Panning B, et al. IRE1 signaling affects cell fate during the unfolded protein response. Science (2007) 318:944-9. doi: 10.1126/science.1146361

32. Lu M, Lawrence DA, Marsters S, Acosta-Alvear D, Kimmig P, Mendez AS, et al. Opposing unfolded-protein-response signals converge on death receptor 5 to control apoptosis. Science (2014) 345:98-101. doi: 10.1126/ science. 1254312

33. Balachandran S, Roberts PC, Brown LE, Truong H, Pattnaik AK, Archer DR, et al. Essential role for the dsRNA-dependent protein kinase PKR in innate immunity to viral infection. Immunity (2000) 13:129-41. doi: 10.1016/ S1074-7613(00)00014-5

34. Gal-Ben-Ari S, Barrera I, Ehrlich M, Rosenblum K. PKR: A Kinase to Remember. Front Mol Neurosci (2018) 11:480. doi: 10.3389/fnmol.2018.00480

35. Vazquez de Aldana CR, Wek RC, Segundo PS, Truesdell AG, Hinnebusch AG. Multicopy tRNA genes functionally suppress mutations in yeast eIF-2 alpha kinase GCN2: evidence for separate pathways coupling GCN4 expression to unchanged tRNA. Mol Cell Biol (1994) 14:7920-32. doi: 10.1128/MCB.14.12.7920

36. Zhou Y, Shu F, Liang X, Chang H, Shi L, Peng X, et al. Ampelopsin induces cell growth inhibition and apoptosis in breast cancer cells through ROS generation and endoplasmic reticulum stress pathway. PLoS One (2014) 9: e89021. doi: 10.1371/journal.pone.0089021

37. Costa-Mattioli M, Walter P. The integrated stress response: From mechanism to disease. Science (2020) 368(6489):eaat5314. doi: 10.1126/ science.aat5314

38. Pakos-Zebrucka K, Koryga I, Mnich K, Ljujic M, Samali A, Gorman AM. The integrated stress response. EMBO Rep (2016) 17:1374-95. doi: 10.15252/ embr.201642195

39. Acosta-Alvear D, Zhou Y, Blais A, Tsikitis M, Lents NH, Arias C, et al. XBP1 controls diverse cell type- and condition-specific transcriptional regulatory networks. Mol Cell (2007) 27:53-66. doi: 10.1016/j.molcel.2007.06.011

40. Lee KP, Dey M, Neculai D, Cao C, Dever TE, Sicheri F. Structure of the dual enzyme Ire1 reveals the basis for catalysis and regulation in nonconventional RNA splicing. Cell (2008) 132:89-100. doi: 10.1016/j.cell.2007.10.057

41. Sriburi R, Jackowski S, Mori K, Brewer JW. XBP1: a link between the unfolded protein response, lipid biosynthesis, and biogenesis of the endoplasmic reticulum. J Cell Biol (2004) 167:35-41. doi: 10.1083/ jcb.200406136

42. Hollien J, Lin JH, Li H, Stevens N, Walter P, Weissman JS. Regulated Ire1dependent decay of messenger RNAs in mammalian cells. J Cell Biol (2009) 186:323-31. doi: 10.1083/jcb.200903014

43. Hollien J, Weissman JS. Decay of endoplasmic reticulum-localized mRNAs during the unfolded protein response. Science (2006) 313:104-7. doi: 10.1126/science.1129631

44. Urano F, Wang X, Bertolotti A, Zhang Y, Chung P, Harding HP, et al. Coupling of stress in the ER to activation of JNK protein kinases by transmembrane protein kinase IRE1. Science (2000) 287:664-6. doi: 10.1126/science.287.5453.664

45. Haze K, Yoshida H, Yanagi H, Yura T, Mori K. Mammalian transcription factor ATF6 is synthesized as a transmembrane protein and activated by proteolysis in response to endoplasmic reticulum stress. Mol Biol Cell (1999) 10:3787-99. doi: 10.1091/mbc.10.11.3787

46. Ye J, Rawson RB, Komuro R, Chen X, Dave UP, Prywes R, et al. ER stress induces cleavage of membrane-bound ATF6 by the same proteases that process SREBPs. Mol Cell (2000) 6:1355-64. doi: 10.1016/S1097-2765(00)00133-7

47. Hassler JR, Scheuner DL, Wang S, Han J, Kodali VK, Li P, et al. The IRE1alpha/XBP1s Pathway Is Essential for the Glucose Response and Protection of beta Cells. PLoS Biol (2015) 13:e1002277. doi: 10.1371/ journal.pbio.1002277
48. Hong M, Li M, Mao C, Lee AS. Endoplasmic reticulum stress triggers an acute proteasome-dependent degradation of ATF6. J Cell Biochem (2004) 92:723-32. doi: $10.1002 / j c b .20118$

49. Hong M, Luo S, Baumeister P, Huang JM, Gogia RK, Li M, et al. Underglycosylation of ATF6 as a novel sensing mechanism for activation of the unfolded protein response. J Biol Chem (2004) 279:11354-63. doi: 10.1074/jbc.M309804200

50. Engin F, Nguyen T, Yermalovich A, Hotamisligil GS. Aberrant islet unfolded protein response in type 2 diabetes. Sci Rep (2014) 4:4054. doi: 10.1038/ srep04054

51. Marre ML, Piganelli JD. Environmental Factors Contribute to beta Cell Endoplasmic Reticulum Stress and Neo-Antigen Formation in Type 1 Diabetes. Front Endocrinol (Lausanne) (2017) 8:262. doi: 10.3389/ fendo.2017.00262

52. Vacaru AM, Di Narzo AF, Howarth DL, Tsedensodnom O, Imrie D, Cinaroglu A, et al. Molecularly defined unfolded protein response subclasses have distinct correlations with fatty liver disease in zebrafish. Dis Model Mech (2014) 7:823-35. doi: 10.1242/dmm.014472

53. Lipson KL, Ghosh R, Urano F. The role of IRE1alpha in the degradation of insulin mRNA in pancreatic beta-cells. PLoS One (2008) 3:e1648. doi: 10.1371/journal.pone.0001648

54. Tsuchiya Y, Saito M, Kadokura H, Miyazaki JII, Tashiro F, Imagawa Y, et al. IRE1-XBP1 pathway regulates oxidative proinsulin folding in pancreatic beta cells. J Cell Biol (2018) 217:1287-301. doi: 10.1083/jcb.201707143

55. Tsuchiya Y, Saito M, Kohno K. Pathogenic Mechanism of Diabetes Development Due to Dysfunction of Unfolded Protein Response. Yakugaku Zasshi (2016) 136:817-25. doi: 10.1248/yakushi.15-00292-4

56. Song B, Scheuner D, Ron D, Pennathur S, Kaufman RJ. Chop deletion reduces oxidative stress, improves beta cell function, and promotes cell survival in multiple mouse models of diabetes. J Clin Invest (2008) 118:337889. doi: 10.1172/JCI34587

57. Satoh T, Abiru N, Kobayashi M, Zhou H, Nakamura K, Kuriya G, et al. CHOP deletion does not impact the development of diabetes but suppresses the early production of insulin autoantibody in the NOD mouse. Apoptosis (2011) 16:438-48. doi: 10.1007/s10495-011-0576-2

58. Engin F, Yermalovich A, Nguyen T, Hummasti S, Fu W, Eizirik DL, et al. Restoration of the unfolded protein response in pancreatic beta cells protects mice against type 1 diabetes. Sci Transl Med (2013) 5:211ra156. doi: 10.1126/ scitranslmed.3006534

59. Bensellam M, Jonas JC, Laybutt DR. Mechanisms of beta-cell dedifferentiation in diabetes: recent findings and future research directions. J Endocrinol (2018) 236:R109-43. doi: 10.1530/JOE-17-0516

60. Xin Y, Dominguez Gutierrez G, Okamoto H, Kim J, Lee AH, Adler C, et al. Pseudotime Ordering of Single Human beta-Cells Reveals States of Insulin Production and Unfolded Protein Response. Diabetes (2018) 67:1783-94. doi: $10.2337 / \mathrm{db} 18-0365$

61. Wasserfall C, Nick HS, Campbell-Thompson M, Beachy D, Haataja L, Kusmartseva I, et al. Persistence of Pancreatic Insulin mRNA Expression and Proinsulin Protein in Type 1 Diabetes Pancreata. Cell Metab (2017) 26:568-75.e563. doi: 10.1016/j.cmet.2017.08.013

62. Talchai C, Xuan S, Lin HV, Sussel L, Accili D. Pancreatic beta cell dedifferentiation as a mechanism of diabetic beta cell failure. Cell (2012) 150:1223-34. doi: 10.1016/j.cell.2012.07.029

63. Sharma RB, O’Donnell AC, Stamateris RE, Ha B, McCloskey KM, Reynolds $\mathrm{PR}$, et al. Insulin demand regulates beta cell number via the unfolded protein response. J Clin Invest (2015) 125:3831-46. doi: 10.1172/JCI79264

64. Cigliola V, Thorel F, Chera S, Herrera PL. Stress-induced adaptive islet cell identity changes. Diabetes Obes Metab (2016) 18(Suppl 1):87-96. doi: 10.1111/dom. 12726

65. Hodish I, Absood A, Liu L, Liu M, Haataja L, Larkin D, et al. In vivo misfolding of proinsulin below the threshold of frank diabetes. Diabetes (2011) 60:2092-101. doi: 10.2337/db10-1671

66. Wang R, Munoz EE, Zhu S, McGrath BC, Cavener DR. Perk gene dosage regulates glucose homeostasis by modulating pancreatic beta-cell functions. PLoS One (2014) 9:e99684. doi: 10.1371/journal.pone.0099684

67. Bernal-Mizrachi E, Kulkarni RN, Scott DK, Mauvais-Jarvis F, Stewart AF, Garcia-Ocana A. Human beta-cell proliferation and intracellular signaling 
part 2: still driving in the dark without a road map. Diabetes (2014) 63:81931. doi: $10.2337 / \mathrm{db} 13-1146$

68. Kulkarni RN, Mizrachi EB, Ocana AG, Stewart AF. Human beta-cell proliferation and intracellular signaling: driving in the dark without a road map. Diabetes (2012) 61:2205-13. doi: 10.2337/db12-0018

69. Garg AD, Kaczmarek A, Krysko O, Vandenabeele P, Krysko DV, Agostinis P. ER stress-induced inflammation: does it aid or impede disease progression? Trends Mol Med (2012) 18:589-98. doi: 10.1016/j.molmed.2012.06.010

70. Brozzi F, Gerlo S, Grieco FA, Juusola M, Balhuizen A, Lievens S, et al. Ubiquitin D Regulates IRE1alpha/c-Jun N-terminal Kinase (JNK) Proteindependent Apoptosis in Pancreatic Beta Cells. J Biol Chem (2016) 291:12040-56. doi: 10.1074/jbc.M115.704619

71. Campbell-Thompson M, Fu A, Kaddis JS, Wasserfall C, Schatz DA, Pugliese A, et al. Insulitis and beta-Cell Mass in the Natural History of Type 1 Diabetes. Diabetes (2016) 65:719-31. doi: 10.2337/db15-0779

72. Coppieters KT, Dotta F, Amirian N, Campbell PD, Kay TW, Atkinson MA, et al. Demonstration of islet-autoreactive CD8 T cells in insulitic lesions from recent onset and long-term type 1 diabetes patients. J Exp Med (2012) 209:51-60. doi: 10.1084/jem.20111187

73. Eizirik DL, Colli ML, Ortis F. The role of inflammation in insulitis and beta-cell loss in type 1 diabetes. Nat Rev Endocrinol (2009) 5:219-26. doi: 10.1038/ nrendo.2009.21

74. Montane J, Cadavez L, Novials A. Stress and the inflammatory process: a major cause of pancreatic cell death in type 2 diabetes. Diabetes Metab Syndr Obes (2014) 7:25-34. doi: 10.2147/DMSO.S37649

75. Demine S, Schiavo AA, Marin-Canas S, Marchetti P, Cnop M, Eizirik DL. Pro-inflammatory cytokines induce cell death, inflammatory responses, and endoplasmic reticulum stress in human iPSC-derived beta cells. Stem Cell Res Ther (2020) 11:7. doi: 10.1186/s13287-019-1523-3

76. Gurzov EN, Eizirik DL. Bcl-2 proteins in diabetes: mitochondrial pathways of beta-cell death and dysfunction. Trends Cell Biol (2011) 21:424-31. doi: 10.1016/j.tcb.2011.03.001

77. Russell MA, Morgan NG. The impact of anti-inflammatory cytokines on the pancreatic beta-cell. Islets (2014) 6:e950547. doi: 10.4161/19382014.2014.950547

78. Tyka K, Jorns A, Turatsinze JV, Eizirik DL, Lenzen S, Gurgul-Convey E. MCPIP1 regulates the sensitivity of pancreatic beta-cells to cytokine toxicity. Cell Death Dis (2019) 10:29. doi: 10.1038/s41419-018-1268-4

79. Grieco FA, Vendrame F, Spagnuolo I, Dotta F. Innate immunity and the pathogenesis of type 1 diabetes. Semin Immunopathol (2011) 33:57-66. doi: 10.1007/s00281-010-0206-Z

80. Ryan GA, Wang CJ, Chamberlain JL, Attridge K, Schmidt EM, Kenefeck R, et al. B1 cells promote pancreas infiltration by autoreactive $\mathrm{T}$ cells. J Immunol (2010) 185:2800-7. doi: 10.4049/jimmunol.1000856

81. Cucak H, Mayer C, Tonnesen M, Thomsen LH, Grunnet LG, Rosendahl A. Macrophage contact dependent and independent TLR4 mechanisms induce beta-cell dysfunction and apoptosis in a mouse model of type 2 diabetes. PloS One (2014) 9:e90685. doi: 10.1371/journal.pone.0090685

82. Eguchi K, Manabe I. Macrophages and islet inflammation in type 2 diabetes. Diabetes Obes Metab (2013) 15(Suppl 3):152-8. doi: 10.1111/dom.12168

83. Hasnain SZ, Borg DJ, Harcourt BE, Tong H, Sheng YH, Ng, et al. Glycemic control in diabetes is restored by therapeutic manipulation of cytokines that regulate beta cell stress. Nat Med (2014) 20(12):1417-26. doi: 10.1038/nm.3705

84. Cardozo AK, Ortis F, Storling J, Feng YM, Rasschaert J, Tonnesen M, et al. Cytokines downregulate the sarcoendoplasmic reticulum pump Ca2+ ATPase $2 \mathrm{~b}$ and deplete endoplasmic reticulum $\mathrm{Ca} 2+$, leading to induction of endoplasmic reticulum stress in pancreatic beta-cells. Diabetes (2005) 54:452-61. doi: 10.2337/diabetes.54.2.452

85. Ortis F, Naamane N, Flamez D, Ladriere L, Moore F, Cunha DA, et al. Cytokines interleukin-1beta and tumor necrosis factor-alpha regulate different transcriptional and alternative splicing networks in primary betacells. Diabetes (2010) 59:358-74. doi: 10.2337/db09-1159

86. DeZwaan-McCabe D, Riordan JD, Arensdorf AM, Icardi MS, Dupuy AJ, Rutkowski DT. The stress-regulated transcription factor $\mathrm{CHOP}$ promotes hepatic inflammatory gene expression, fibrosis, and oncogenesis. PloS Genet (2013) 9:e1003937. doi: 10.1371/journal.pgen.1003937

87. Suzuki T, Gao J, Ishigaki Y, Kondo K, Sawada S, Izumi T, et al. ER Stress Protein CHOP Mediates Insulin Resistance by Modulating Adipose Tissue Macrophage Polarity. Cell Rep (2017) 18:2045-57. doi: 10.1016/j.celrep.2017.01.076
88. Diana J, Gahzarian L, Simoni Y, Lehuen A. Innate immunity in type 1 diabetes. Discovery Med (2011) 11:513-20.

89. Meyerovich K, Ortis F, Cardozo AK. The non-canonical NF-kappaB pathway and its contribution to beta-cell failure in diabetes. $J$ Mol Endocrinol (2018) 61:F1-6. doi: 10.1530/JME-16-0183

90. Meyerovich K, Ortis F, Allagnat F, Cardozo AK. Endoplasmic reticulum stress and the unfolded protein response in pancreatic islet inflammation. J Mol Endocrinol (2016) 57:R1-R17. doi: 10.1530/JME-15-0306

91. Keller G. Embryonic stem cell differentiation: emergence of a new era in biology and medicine. Genes Dev (2005) 19:1129-55. doi: 10.1101/gad. 1303605

92. Swisa A, Glaser B, Dor Y. Metabolic Stress and Compromised Identity of Pancreatic Beta Cells. Front Genet (2017) 8:21. doi: 10.3389/fgene. 2017.00021

93. Cinti F, Bouchi R, Kim-Muller JY, Ohmura Y, Sandoval PR, Masini M, et al. Evidence of beta-Cell Dedifferentiation in Human Type 2 Diabetes. J Clin Endocrinol Metab (2016) 101:1044-54. doi: 10.1210/jc.2015-2860

94. Efrat S. Beta-Cell Dedifferentiation in Type 2 Diabetes: Concise Review. Stem Cells (2019) 37:1267-72. doi: 10.1002/stem.3059

95. Hunter CS, Stein RW. Evidence for Loss in Identity, De-Differentiation, and Trans-Differentiation of Islet beta-Cells in Type 2 Diabetes. Front Genet (2017) 8:35. doi: 10.3389/fgene.2017.00035

96. Weir GC, Aguayo-Mazzucato C, Bonner-Weir S. beta-cell dedifferentiation in diabetes is important, but what is it? Islets (2013) 5:233-7. doi: 10.4161/isl.27494

97. Rahier J, Guiot Y, Goebbels RM, Sempoux C, Henquin JC. Pancreatic betacell mass in European subjects with type 2 diabetes. Diabetes Obes Metab (2008) 10(Suppl 4):32-42. doi: 10.1111/j.1463-1326.2008.00969.x

98. Zhu Y, Sun Y, Zhou Y, Zhang Y, Zhang T, Li Y, et al. MicroRNA-24 promotes pancreatic beta cells toward dedifferentiation to avoid endoplasmic reticulum stress-induced apoptosis. J Mol Cell Biol (2019) 11:747-60. doi: 10.1093/jmcb/mjz004

99. Lee H, Lee YS, Harenda Q, Pietrzak S, Oktay HZ, Schreiber S, et al. Beta Cell Dedifferentiation Induced by IRE1alpha Deletion Prevents Type 1 Diabetes. Cell Metab (2020) 31:822-36.e825. doi: 10.1016/j.cmet.2020.03.002

100. Starling S. beta-cell dedifferentiation prior to insulitis prevents T1DM. Nat Rev Endocrinol (2020) 16:301. doi: 10.1038/s41574-020-0358-4

101. Lin HM, Lee JH, Yadav H, Kamaraju AK, Liu E, Zhigang D, et al. Transforming growth factor-beta/Smad3 signaling regulates insulin gene transcription and pancreatic islet beta-cell function. J Biol Chem (2009) 284:12246-57. doi: 10.1074/jbc.M805379200

102. Rezania A, Riedel MJ, Wideman RD, Karanu F, Ao Z, Warnock GL, et al. Production of functional glucagon-secreting alpha-cells from human embryonic stem cells. Diabetes (2011) 60:239-47. doi: 10.2337/db10-0573

103. Blum B, Roose AN, Barrandon O, Maehr R, Arvanites AC, Davidow LS, et al. Reversal of beta cell de-differentiation by a small molecule inhibitor of the TGFbeta pathway. Elife (2014) 3:e02809. doi: 10.7554/eLife.02809

104. Sun S, Shi G, Han X, Francisco AB, Ji Y, Mendonca N, et al. Sel1L is indispensable for mammalian endoplasmic reticulum-associated degradation, endoplasmic reticulum homeostasis, and survival. Proc Natl Acad Sci USA (2014) 111:E582-91. doi: 10.1073/pnas.1318114111

105. Shrestha N, Liu T, Ji Y, Reinert RB, Torres M, Li X, et al. Sel1L-Hrd1 ERassociated degradation maintains beta cell identity via TGF-beta signaling. J Clin Invest (2020) 130:3499-510. doi: 10.1172/JCI134874

106. Matus S, Lisbona F, Torres M, Leon C, Thielen P, Hetz C. The stress rheostat: an interplay between the unfolded protein response (UPR) and autophagy in neurodegeneration. Curr Mol Med (2008) 8:157-72. doi: 10.2174/ 156652408784221324

Conflict of Interest: The authors declare that the research was conducted in the absence of any commercial or financial relationships that could be construed as a potential conflict of interest.

Copyright (c) 2021 Lenghel, Gheorghita, Vacaru and Vacaru. This is an open-access article distributed under the terms of the Creative Commons Attribution License (CC BY). The use, distribution or reproduction in other forums is permitted, provided the original author(s) and the copyright owner(s) are credited and that the original publication in this journal is cited, in accordance with accepted academic practice. No use, distribution or reproduction is permitted which does not comply with these terms. 